\title{
Good response to methotrexate is associated with a decrease in the gene expression of the drug transporter $A B C G 2$ in patients with rheumatoid arthritis
}

Satoshi Muto

Toho University

Nana Minamitani

Toho University

Takehisa Ogura

Toho University

Arata Nakajima

Toho University

Koichi Nakagawa

Toho University

Toru Masaka

Toho University

\section{Sumiko Hiura}

Toho University Ohashi Medical Center

Hideki Kobayashi

Toho University Ohashi Medical Center

Hiroyoshi Kato

Toho University

Hideto Kameda ( $\nabla$ hideto.kameda@med.toho-u.ac.jp )

Toho University https://orcid.org/0000-0002-4330-5782

Research article

Keywords: ABCG2, drug transporter, methotrexate, response, rheumatoid arthritis

Posted Date: May 15th, 2020

DOl: https://doi.org/10.21203/rs.3.rs-28597/v1

License: (c) (i) This work is licensed under a Creative Commons Attribution 4.0 International License.

Read Full License 
Version of Record: A version of this preprint was published on January 25th, 2021. See the published version at https://doi.org/10.1080/14397595.2021.1879429. 


\section{Abstract}

Background Methotrexate (MTX) is an anchor drug in the treatment of rheumatoid arthritis (RA). We previously performed a cross-sectional, observational study and reported an association between the gene expression level of the drug transporter ABCG2/BCRP (breast cancer resistance protein) and RA disease control in patients receiving MTX.

Methods We designed a prospective study in two medical centers in Japan to confirm the association of ABCG2 gene expression level with the clinical response to MTX in MTX-naive patients with RA. The primary endpoint of this study was good response based on the European League Against Rheumatism (EULAR) response criteria by Disease Activity Score using 28-joint count (DAS28). We evaluated the association between the baseline expression of six genes involved in the intracellular pharmacokinetics of MTX, including ABCG2, as well as their temporal changes, and the clinical response at week 12 from the initiation of MTX.

Results Based on the clinical response at 12 weeks after the initiation of MTX, a total of 24 patients were classified into the good responders $(n=9)$ and non-good responders $(n=15 ; 10$ moderate responders and 5 non-responders) groups. A univariate logistic regression analysis of baseline gene expression levels for the prediction of the EULAR good response at week 12 showed a significant association with ABCG2 alone, and the rate of baseline expression of ABCG2 mRNA above the cut-off value determined by a receiver operating characteristic curve was higher in good responders than in non-good responders $(p=$ 0.012). Moreover, ABCG2 expression decreased in almost all good responders, but not in non-good responders, after MTX treatment for 12 weeks (median $-76 \%$ versus $+41 \%$ from baseline, respectively; $p=$ 0.011). The ABCG2 gene expression level did not correlate with DAS28 at baseline or at week 12, and neither did the rate of change in ABCG2 gene expression level.

Conclusions We have confirmed the association between the gene expression level of the drug transporter ABCG2 and the clinical response to MTX in patients with RA.

\section{Background}

Methotrexate (MTX) is a first-line therapeutic drug for the treatment of rheumatoid arthritis (RA), it is the anchor drug for disease-modifying anti-rheumatic drugs (DMARDs), and it is used throughout the world for treatment-naïve, active RA patients [1-3]. Approximately $30 \%$ of early RA patients achieve clinical remission with MTX monotherapy after six months treatment $[4,5]$. The remaining patients are classified as partial responders or non-responders and treatment with additional DMARDs is required according to the "treat to target" strategy [6].

The prediction of the clinical and radiographic effectiveness of MTX is still a distinct issue of interest. In addition to lower disease activity, male sex, lack of seropositivity, lower serum tumor necrosis factor (TNF), and levels of TNF-producing cells in the peripheral blood were all previously associated with clinical effectiveness [7-10]. More recently, activity in daily life as measured by the health assessment 
questionnaire-disability index (HAQ-DI), body mass index, anxiety/depression, and smoking/alcohol were also demonstrated to show an association [11-13]. In addition, the gene expression profiles of biomolecules involved in the intracellular pharmacokinetics of MTX are likely to play a crucial role in the prediction of clinical response [11,14], as are the development of dose-dependent adverse events such as liver dysfunction and cytopenia.

In the present study, our aim was to identify a simple method to predict the clinical response to MTX by investigating the expression of six genes involved in the intracellular pharmacokinetics of MTX. MTX is transported into target cells through a transporter, reduced folate carrier 1 (RFC-1) $[15,16]$, and converted to polyglutamated MTX (MTX-PG) by folylpolyglutamyl synthase (FPGS) [17]. MTX-PG is very stable in the intracellular compartment, where it inhibits dihydrofolate reductase (DHFR) significantly more potently than non-polyglutamated MTX [18-21], resulting in an inhibition of DNA synthesis. MTX-PG is reconverted to MTX by $Y$-glutamyl hydrolase $(\mathrm{GGH})[22,23]$, and is excluded through transporters such as the ATP-binding cassette sub-family $\mathrm{C}$ member 1 (ABCC1)/multidrug-resistance associated protein 1 (MRP-1) [24] and the ATP-binding cassette sub-family G member 2 (ABCG2)/ breast cancer resistance protein (BCRP) $[25,26]$. The latter transporter, ABCG2, can also exclude MTX-PG, in addition to MTX [27, 28].

In our previous cross-sectional study, we found that the gene expression levels of ABCG2 were higher in active RA patients (irrespective of MTX therapy) than in inactive patients with MTX therapy [29]. The results suggest that high ABCG2 expression is associated with active exclusion of MTX from the cells, placing a high burden on the action of MTX. However, whether baseline expression of ABCG2, or that of other relevant genes, has a predictive potential for the clinical response to MTX in RA patients is not known. Moreover, reduced ABCG gene expression may be a result of RA disease control with MTX.

We have therefore designed a prospective study for the evaluation of the association of the baseline expression of six genes (all involved in the intracellular pharmacokinetics of MTX) and the changes in their expression over time with the clinical response at 12 weeks (after the initiation of MTX) in MTXnaïve patients with RA. The data presented here helps to inform an interpretation of our previous observations from a cross-sectional study.

\section{Methods}

\section{Patients}

Patients with MTX-naïve RA visiting Toho University Ohashi Medical Center or Sakura Medical Center were enrolled in this study before starting MTX between April 2017 and September 2018. Patients without indication of MTX [3] and those with history of MTX treatment were excluded from the study.

\section{Study design and the primary endpoint}


This is a pilot prospective study performed in two medical centers in Japan. After obtaining written informed consent from the patients to participate in this study, blood was sampled at baseline (before starting MTX) and again after three months. The primary endpoint of this study was good response based on the European League Against Rheumatism (EULAR) response criteria by Disease Activity Score using 28-joint count (DAS28) [30]. The sample size was initially calculated by an estimation using 15 good responders and 35 moderate or non-responders (non-good responders) for obtaining analyses between two or three groups according to clinical response to MTX. However, due to the delayed patient recruitment, we terminated recruitment halfway through the study and focused on an analysis between good responders and non-good responders. This study was approved by three Ethics Committees of Toho University (the Faculty of Pharmaceutical Sciences [approval number 2017-001], Ohashi Medical Center [approval number H16096], and Sakura Medical Center [approval number S17009]).

\section{Clinical assessment of RA}

The following demographic and clinical data were obtained from the patients at baseline and after 12 weeks: sex; age; disease duration; height; weight; body mass index (BMI); anti-cyclic citrullinated peptide (CCP) antibody; rheumatoid factor (RF); Steinbrocker's radiographic stage and functional class; tender joint count-28 (TJC); swollen joint count-28 (SJC); patient global assessment (PtGA); health assessment questionnaire-disability index (HAQ-DI); erythrocyte sedimentation rate (ESR); C-reactive protein (CRP); DAS28 based on ESR; the Simplified Disease Activity Index (SDAI); and the dose of MTX.

\section{RNA extraction and real-time polymerase chain reaction (PCR)}

EDTA-treated venous blood $(10 \mathrm{~mL})$ samples were collected from patients. Peripheral blood mononuclear cells (PBMCs) were isolated from the samples on the same day (or the next day after storage in a refrigerator) by density gradient centrifugation using a Histopaque 1077 (Sigma), washed three times by centrifugation with PBS, and used for RNA extraction. Total RNA was extracted from the patient PBMCs using ISOGEN reagents (Wako), according to the manufacturer's instructions. Total RNA was treated with TURBO DNA-free (Ambion) to remove any possible contaminating DNA. CDNA was prepared from the above DNase I-treated total RNA using ReverTra Ace-a (Toyobo).

cDNA isolated as described above was used as a DNA template for the assessment of gene expression. Quantitative analyses of ABCC1, ABCG2, DHFR, FPGS, GGH, and RFC mRNA expression levels were performed by real-time PCR using an ABI 7500 Fast Real-Time PCR System (Applied Biosystems). TaqMan Gene Expression Master Mix (Applied Biosystems) and TaqMan Gene Expression Assays (Hs00219905_m1 for ABCC1, Hs00184979_m1 for ABCG2, Hs00758822_s1 for DHFR, Hs00191956_m1 for FPGS, Hs00914163_m1 for GGH, Hs00953344_m1 for RFC, and Hs99999905_m1 for glyceraldehyde3-phosphate dehydrogenase [GAPDH]) were used for all quantitative real-time PCR assays. The samples were incubated at $50^{\circ} \mathrm{C}$ for $2 \mathrm{~min}$, and $95^{\circ} \mathrm{C}$ for $10 \mathrm{~min}$, then amplification was carried out for 40 cycles (each cycle: at $95^{\circ} \mathrm{C}$ for $15 \mathrm{~s}$, annealing at $60^{\circ} \mathrm{C}$ for $1 \mathrm{~min}$ ). All assays were performed in duplicate in 96well plates. The expression levels of all genes of interest were normalized against the expression level of 
GAPDH and expressed as a percentage. The complete real-time PCR experiment was repeated two or three times for each patient sample, and the mean expression level of each gene in each patient was calculated.

\section{Statistical analyses}

Statistical analysis was performed using EZR software (Saitama Medical Center, Jichi Medical University, Saitama, Japan, version 1.37) [31], which provides a graphical user interface for $\mathrm{R}$ (The R Foundation for Statistical Computing, Vienna, Austria, version 3.4.1), and complemented by JMP Pro (version 14.2.0, SAS Institute Japan Ltd., Tokyo, Japan) for the drawing of Supplementary Fig. 1. Continuous variables were summarized using medians and interquartile ranges (IQRs) and analyzed using the Mann-Whitney U test or the Kruskal-Wallis rank sum test, while binominal data from the two groups were examined with the Fisher's exact test. The relationships among the continuous variables were assessed using the Spearman's rank correlation coefficient. We conducted logistic regression analyses followed by receiver operating characteristics (ROC) analyses for baseline gene expression levels to predict EULAR good response. Cut-off values were determined according to the maximal Youden Index, which represents the highest combination of sensitivity and specificity. $P$ values $<0.05$ were considered statistically significant.

\section{Results}

\section{Characteristics of the patients}

Patient characteristics and disease activities prior to the administration of MTX are shown in Table 1. Based on their response at 12 weeks after the initiation of MTX treatment (according to EULAR criteria), 24 patients were classified into good responders $(n=9)$ and non-good responders $(n=15 ; 10$ moderate responders and 5 non-responders) groups. All demographic and clinical characteristics were comparable between the good responders group and the non-good responders group. The median dose of MTX was $6 \mathrm{mg} /$ week initially and $10 \mathrm{mg} /$ week at week 12 in both groups. All of the enrolled patients completed the 12-week study without any adverse events or drop-outs. 
Table 1

Patient characteristics

\begin{tabular}{|c|c|c|c|c|c|}
\hline & & Total & Good & Non-good & $\begin{array}{l}\text { p- } \\
\text { value }\end{array}$ \\
\hline & & $(n=24)$ & $(\mathrm{n}=9)$ & $(n=15)$ & \\
\hline Sex, female & & $18(75)$ & $5(56)$ & $13(87)$ & 0.150 \\
\hline Age & & $58(46-70)$ & $69(51-73)$ & $53(45-67)$ & 0.245 \\
\hline Disease duration, years & & $0.8(0.3-1.0)$ & $0.8(0.3-1.5)$ & $0.8(0.4-2.0)$ & 0.571 \\
\hline Height, cm & & $161(155-167)$ & $163(159-167)$ & $159(155-167)$ & 0.437 \\
\hline Weight, kg & & $59(50-60)$ & $58(57-61)$ & $52(47-59)$ & 0.099 \\
\hline BMI & & $\begin{array}{l}21.8(19.8- \\
22.8)\end{array}$ & $\begin{array}{l}22.5(20.8- \\
24.0)\end{array}$ & $\begin{array}{l}21.8(18.7- \\
22.3)\end{array}$ & 0.121 \\
\hline TJC & & $2(1-4)$ & $4(2-6)$ & $2.1(0-4)$ & 0.204 \\
\hline SJC & & $4(2-6)$ & $4(3-6)$ & $3(2-7)$ & 0.674 \\
\hline PtGA & & $41(20-53)$ & $32(24-45)$ & $44(17-74)$ & 0.612 \\
\hline DAS28-ESR & & $\begin{array}{l}4.54(3.52- \\
5.44)\end{array}$ & $\begin{array}{l}4.61(4.07- \\
5.32)\end{array}$ & $\begin{array}{l}4.16(3.09- \\
5.74)\end{array}$ & 0.404 \\
\hline HAQ-DI & & $0.6(0-1.1)$ & $0.6(0.4-1.0)$ & $0.8(0-1.5)$ & 0.912 \\
\hline \multirow{3}{*}{$\begin{array}{l}\text { Steinbrocker classification } \\
\text { class }\end{array}$} & प & $7(42)$ & $3(33)$ & $4(27)$ & 0.678 \\
\hline & प & $15(63)$ & $6(7)$ & $9(60)$ & - \\
\hline & प & $2(8)$ & $0(0)$ & $2(13)$ & - \\
\hline \multirow[t]{2}{*}{$\begin{array}{l}\text { Steinbrocker's radiographic } \\
\text { stage }\end{array}$} & 口 & $13(54)$ & $6(67)$ & $7(47)$ & 0.423 \\
\hline & ए & $11(46)$ & $3(33)$ & $8(53)$ & - \\
\hline
\end{tabular}

The values are expressed as median (IQR) and number (\%). A Fisher's exact test or Mann-Whitney U test was used for group comparisons.

BMI, Body mass index; TJC, tender joint count; SJC, swollen joint count; PtGA, physician's global assessment; DAS28-ESR, Disease Activity Score 28-ESR; HAQ-DI, Health Assessment Questionnaire disability index; CRP, serum C-reactive protein; ESR, erythrocyte sedimentation rate; RF, rheumatoid factor; CCP, cyclic citrullinated peptide; MTX, methotrexate.

aRF positive, > $15 \mathrm{IU} / \mathrm{mL}$.

${ }^{\mathrm{b}}$ Anti-CCP positive, $\geq 4.5 \mathrm{U} / \mathrm{mL}$. 


\begin{tabular}{|c|c|c|c|c|}
\hline & Total & Good & Non-good & $\begin{array}{l}\text { p- } \\
\text { value }\end{array}$ \\
\hline CRP, mg/dL & $\begin{array}{l}2.21(0.40- \\
6.53)\end{array}$ & $\begin{array}{l}2.31(0.62- \\
4.87)\end{array}$ & $\begin{array}{l}0.79(0.08- \\
7.36)\end{array}$ & 0.743 \\
\hline $\mathrm{ESR}, \mathrm{mm} / \mathrm{hr}$ & $52(22-75)$ & 54.(24-73) & $36(20-80)$ & 0.952 \\
\hline RF positive ${ }^{a}$ & $11(46)$ & $5(56)$ & $6(40)$ & 0.675 \\
\hline Anti-CCP positive ${ }^{\mathrm{b}}$ & $10(42)$ & $4(44)$ & $6(40)$ & 1.000 \\
\hline \multicolumn{5}{|l|}{ MTX, mg/week } \\
\hline baseline (initial dose) & $6(6-8)$ & $6(6-8)$ & $6(6-7)$ & 0.733 \\
\hline at week 12 & $10(8-12)$ & $10(8-16)$ & $10(8-10)$ & 0.389 \\
\hline \multicolumn{5}{|c|}{$\begin{array}{l}\text { The values are expressed as median (IQR) and number (\%). A Fisher's exact test or Mann-Whitney U } \\
\text { test was used for group comparisons. }\end{array}$} \\
\hline \multicolumn{5}{|c|}{$\begin{array}{l}\text { BMI, Body mass index; TJC, tender joint count; SJC, swollen joint count; PtGA, physician's global } \\
\text { assessment; DAS28-ESR, Disease Activity Score 28-ESR; HAQ-DI, Health Assessment Questionnaire } \\
\text { disability index; CRP, serum C-reactive protein; ESR, erythrocyte sedimentation rate; RF, rheumatoid } \\
\text { factor; CCP, cyclic citrullinated peptide; MTX, methotrexate. }\end{array}$} \\
\hline \multicolumn{5}{|l|}{${ }^{\mathrm{a}} \mathrm{RF}$ positive, > $15 \mathrm{IU} / \mathrm{mL}$. } \\
\hline${ }^{\mathrm{b}}$ Anti-CCP positive, $\geq 4$ & & & & \\
\hline
\end{tabular}

\section{Comparison of gene expression levels between the response groups}

First, we analyzed the expression levels of the six genes of interest (ABCC1, ABCG2, DHFR, FPGS, GGH and RFC1) by subgroup (good responders vs. non-good responders) before and after the initiation of MTX treatment. Interestingly, a clear separation of good responders from non-good responders was observed for ABCG2, but not for the other genes (Fig. 1). The baseline expression of ABCG2 tended to be higher in good responders than in non-good responders. However, the difference was not significant for the ABCG2 gene (or other five genes) either at baseline or at week 12. Although ABCG2 expression decreased in almost all good responders after MTX treatment for 12 weeks, no comparable decrease was observed in non-good responders. The univariate logistic regression analysis of baseline gene expression levels for the prediction of the EULAR good response at week 12 showed a significant association in ABCG2 alone ( $p=0.0064$, Supplementary Fig. 1$)$. Moreover, the rate of baseline expression of ABCG2 mRNA above the cut-off value determined by the logistic regression analysis was higher in good responders than in non-good responders ( $p=0.012$, Table 2$)$. The same rate was comparable between good responders and non-good responders in the remaining five genes. 
Table 2

Prediction of the EULAR good response by the baseline expression level of MTX related genes

\begin{tabular}{|c|c|c|c|c|c|c|}
\hline mRNA & $\begin{array}{l}\text { Gene } \\
\text { expression } \\
\text { levels }\end{array}$ & $\begin{array}{l}\text { Cut- } \\
\text { off } \\
\text { value }\end{array}$ & AUC & $\begin{array}{l}\text { Number of patients } \\
(\%)>\text { the cut-off value } \\
\text { in good responders } \\
(n=9)\end{array}$ & $\begin{array}{l}\text { Number of patients (\%) } \\
>\text { the cut-off value in } \\
\text { non-good responders } \\
(n=15)\end{array}$ & $\begin{array}{l}\mathrm{P} \\
\text { value }\end{array}$ \\
\hline$A B C C 1$ & $\begin{array}{l}0.48 \\
(0.27- \\
1.53)\end{array}$ & 0.44 & 0.59 & $4(44)$ & $10(67)$ & 0.40 \\
\hline ABCG2 & $\begin{array}{l}0.22 \\
(0.10- \\
0.41)\end{array}$ & 0.64 & 0.67 & $4(44)$ & $0(0)$ & 0.012 \\
\hline DHFR & $\begin{array}{l}6.61 \\
(4.06- \\
9.76)\end{array}$ & 1.93 & 0.53 & $8(89)$ & $11(73)$ & 0.62 \\
\hline FPGS & $\begin{array}{l}8.28 \\
(5.77- \\
14.1)\end{array}$ & 11.36 & 0.53 & $1(11)$ & $6(40)$ & 0.19 \\
\hline GGH & $\begin{array}{l}9.15 \\
(0.36- \\
15.8)\end{array}$ & 0.14 & 0.51 & 8 (89) & $12(80)$ & 1.0 \\
\hline RFC1 & $\begin{array}{l}2.59 \\
(1.91- \\
4.52)\end{array}$ & 2.61 & 0.59 & $5(56)$ & $6(40)$ & 0.68 \\
\hline \multicolumn{7}{|c|}{ The gene expression levels are expressed as median (IQR). } \\
\hline$J C, A$ & $r+t$ & & & & & \\
\hline
\end{tabular}

A significant difference was observed between the rates of change in ABCG2 gene expression levels between good responders and non-good responders (median $-76 \%$ versus $+41 \%$ from baseline, respectively; $p=0.011$ ) during MTX treatment for 12 weeks, although no similar change was observed for the remaining five genes (Fig. 2). These results were further confirmed by a correlation analysis of gene expression between baseline and week 12. The results of the correlation analysis showed distinct subgroups of good and non-good responders in ABCG2 gene expression (Supplementary Fig. 2).

\section{Correlation between RA disease activity and ABCG2 gene expression}

Finally, we examined whether the above findings were attributable to an association between RA disease activity (as defined by DAS28 score) and the ABCG2 gene expression level. The ABCG2 gene expression level did not correlate with DAS28 at baseline or at week 12 (Fig. 3A and Fig. 3B, respectively). Moreover, no correlation was observed between the rate of change in DAS28 score and the rate of change of ABCG2 
gene expression (Fig. 3C). Therefore, the significant decrease in ABCG gene expression observed in good responders during MTX treatment for 12 weeks was not simply attributable to decreased RA activity.

\section{Discussion}

Our previous cross-sectional study revealed that amongst the six genes involved in the intracellular pharmacokinetics of MTX, the gene expression level of ABCG2 was significantly lower in MTX responders than in non-responders. To elucidate the cause-effect relationship between clinical response to MTX and ABCG2 gene expression, we performed a prospective study, in which ABCG2 expression levels, and those of the other five genes involved in the intracellular pharmacokinetics of MTX, were examined at baseline and at week 12 after the initial treatment of RA with MTX. As in the previous study, an association between ABCG2 expression and clinical response to MTX in RA patients was demonstrated. No similar association was observed with expression of the other five genes. While the baseline expression of ABCG2 was noticeably higher in good responders (compared with non-good responders), the reduction in ABCG2 gene expression was significantly greater in good responders compared with non-good responders $(p=0.011)$. As a result, mRNA expression of the ABCG2 gene at week 12 was lower in good responders compared with non-good responders (median 0.098 vs 0.23 , respectively). A significant association of the reduction of ABCG2 mRNA expression with the EULAR response was also confirmed by a comparison among good-, moderate- and non-responders ( $p=0.031$; Supplementary Fig. 3 ).

One patient in the good responders group showed a 4.6-fold increase in ABCG2 expression (Fig. 2B and Supplementary Figs. 2 and 3). In the same patient, PtGA (/ $100 \mathrm{~mm})$ decreased from 92 at baseline to 15 at week 12, although objective findings such as SJC or ESR/CRP remained unchanged. Thus, the association between ABCG2 gene expression and clinical response to MTX in RA is convincing. Despite previous reports on the prediction of clinical response to MTX in RA patients [7-14], the "treat-to target" strategy has been dependent on a "trials and errors" algorithm [6]. Although our sample size was limited, the demographic and clinical features of our patients were comparable between the good responders group and the non-good responders group. Only $40-50 \%$ of patients were seropositive, which may be partially associated with the relatively short disease duration (median 0.8 years). In order to improve the accuracy of the prediction of clinical response to MTX, an analysis of several different cell types, including T cells, B cells, NK cells, monocytes, and fibroblast-like synoviocytes, should be included in a future study [32]. We have previously reported a similar study on the baseline gene expression signatures predicting clinical responses to three biologic agents (infliximab, tocilizumab, and abatacept) in RA [33].

It should be noted that the association of ABCG2 gene expression and clinical response to MTX could not be simply explained by RA disease activity. In order to clarify the underlining mechanisms, the effects of pro-inflammatory cytokines on the expression of $A B C G 2$ should be considered. Since it has previously been reported that activation of NF-KB can increase the expression of ABCG2 [34, 35], pro-inflammatory cytokines may be responsible for the increased expression of ABCG2 observed here. Moreover, several other studies have reported that ABCG2 expression in MCF-7 human breast carcinoma cell lines was increased after treatment with IL-1 $\beta$ or TNFa [36], and that this increase in ABCG2 expression was 


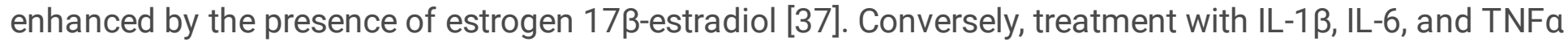
cytokines was shown to reduce ABCG2 expression in hCMEC/D3 cell lines (a model of the human bloodbrain barrier) [38] and in cervical cancer HeLa cell lines [39]. Thus, the effects of pro-inflammatory cytokines on ABCG2 expression may be specific to cells and tissues, and ABCG2 expression may be affected by the presence of other factors. However, we could not observe any correlation between ABCG2 gene expression and DAS28 (Fig. 3) or CRP (data not shown).

The limitations of this study include the small sample size and the analysis of expression of only six genes in PBMC. Nonetheless, the prospective nature of this study has enabled us to clarify the interpretation of our previous results [29].

\section{Conclusions}

In the present study, we have confirmed the association between the gene expression level of the drug transporter ABCG2 and the clinical response to MTX in patients with RA. Our results may justify a dose reduction of MTX in RA patients with sustained remission, and this should be a future perspective to be investigated.

\section{Abbreviations}

MTX, methotrexate; DMARDs, disease-modifying antirheumatic drugs; RA, rheumatoid arthritis; RFC-1, reduced folate carrier 1; MTX-PG polyglutamated MTX; FPGS folylpolyglutamyl synthase; DHFR, dihydrofolate reductase; $\mathrm{GGH}$, $ү$-glutamyl hydrolase; $\mathrm{ABCC1}$, ATP-binding cassette sub-family $\mathrm{C}$ member 1; MRP-1, multidrug-resistance associated protein 1; ABCG2, ATP-binding cassette sub-family $G$ member 2; BCRP, breast cancer resistance protein; EULAR, European League Against Rheumatism; CCP, anti-cyclic citrullinated peptide; RF, rheumatic factor; TJC28, tender joint count-28; SJC28, swollen joint count-28; ESR, erythrocyte sedimentation rate; CRP, C-reactive protein; DAS28, Disease Activity Score 28-joint count; SDAI, Simplified Disease Activity Index; PCR, polymerase chain reaction; PBMCs, peripheral blood mononuclear cells; GAPDH, glyceraldehyde-3-phosphate dehydrogenase.

\section{Declarations}

\section{Ethics approval and consent to participate}

This study was conducted with the approval of the ethics committees at the Faculty of Pharmaceutical Science [2017-001] and at each hospital (Ohashi Medical Center [H16096] and Sakura Medical Center [S17009]) in Toho University.

\section{Consent for publication}




\section{Availability of data and materials}

The datasets used and/or analyzed during the present study are available from the corresponding authors on reasonable request.

\section{Competing interests}

The authors declare no conflicts of interest in association with the present study.

\section{Funding}

This study was supported by research funds provided by Toho University.

\section{Authors' contributions}

$\mathrm{SM}, \mathrm{AN}$, and HKam were involved in the planning of this study and played a central role in advancing the study, making significant comments on the final data discussion. AN, TO, and HKam were also involved in recruiting subjects, collecting clinical data, and identifying clinical symptoms. TO, KN, TM, SH, HKob, and HKat were involved in the handling and statistical processing of clinical specimens and data. SM and AN contributed to the analysis of gene expression. The writing of the thesis was mainly completed by SM and HKam. The manuscript was finalized after a thorough review of all contents by the other authors. All of the authors read the final manuscript and agree to its submission.

\section{Acknowledgements}

We would like to thank the patients who participated in this study, and Editage (www.editage.com) for English language editing.

\section{Author details}


${ }^{1}$ Center of Pharmaceutical Health Care and Sciences, Faculty of Pharmaceutical Sciences, Toho University, 2-2-1 Miyama, Funabashi-City, Chiba 274-8510, Japan. ${ }^{2}$ Division of Rheumatology, Department of Internal Medicine, Toho University Ohashi Medical Center, 2-22-36 Ohashi, Meguro-ku, Tokyo 153-8515, Japan. ${ }^{3}$ Department of Orthopaedic Surgery, Toho University Sakura Medical Center, 564-1 Shimoshizu, Sakura, Chiba 285-8741, Japan. ${ }^{4}$ Department of Pharmacy, Toho University Sakura Medical Center, 564-1 Shimoshizu, Sakura, Chiba 285-8741, Japan. ${ }^{5}$ Department of Pharmacy, Toho University Ohashi Medical Center, 2-22-36 Ohashi, Meguro-ku, Tokyo 153-8515, Japan:

\section{References}

1. Smolen JS, Landewé RBM, Bijisma JWJ, Burmester GR, Dougados M, Kerschbaumer A, et al. EULAR recommendationsfor the management of rheumatoid arthritis with synthetic and biological diseasemodifying anturheumatic drugs: 2019 update. Ann Rheum Dis 2020 Jan 22. doi: 10.1136/annrheumdis-2019-216655.

2. Singh JA, Saag KG, Bridges SL Jr, Akl EA, Bannuru RR, Sullivan MC, et al. 2015 American College of Rheumatology guideline for the treatment of rheumatoid arthritis. Arthritis Rheumatol 2016;68:1-26.

3. Kameda H, Fujii T, Nakajima A, Koike R, Sagawa A, Kanbe K, et al; Japan College of Rheumatology subcommittee on the guideline for the use of methotrexate in patients with rheumatoid arthritis. Japan College of Rheumatology guideline for the use of methotrexate in patients with rheumatoid arthritis. Mod Rheumatol. 2019;29:31-40.

4. Atsumi T, Yamamoto $K$, Takeuchi T, Yamanaka $H$, Ishiguro $N$, Tanaka $Y$, et al. The first double-blind, randomized, parallel-group certolizumab pegol study in methotrexate-naiveearly rheumatoid arthritis patients with poor prognostic factors, C-OPERA, shows inhibition of radiographic progression. Ann Rheum Dis 2016;75:75-83.

5. Emery P, Horton S, Dumitru RB, Naraghi K, van der Heijde D, Wakefield RJ, et al. Pragmatic randomized controlled trial of very early etanercept and MTX versus MTX with delayed etanercept in RA: the VEDERA trial. Ann Rheum Dis (in press), doi:10.1136/annrheumdis-2019-216539.

6. Smolen JS, Breedveld FC, Burmester GR, Bykerk V, Dougados M, Emery P, et al. Treating rheumatoid arthritis to target: 2014 update of the recommendations of an international task force. Ann Rheum Dis 2016;75:3-15.

7. Kameda H, Amano K, Sekiguchi N, Takei H, Ogawa H, Nagasawa $H$, et al. Factors predicting the response to low-dose methotrexate therapy in patients with rheumatoid arthritis: a better response in male patients. Mod Rheumatol 2004;14:442-446.

8. Visser K, Goekoop-Ruiterman YP, de Vries-Bouwstra JK, Ronday HK, Seys PE, Kerstens PJ, et al. A matrix risk model for the prediction of rapid radiographic progression in patients with rheumatoid arthritis receiving different dynamic treatment strategies: post hoc analyses from the BeSt study. Ann Rheum Dis 2010;69:1333-1337. 
9. Nishina N, Kaneko Y, Kameda H, Kuwana M, Takeuchi T. Reduction f plasma IL-6 but not TNF-a by methotrexate in patients with early rheumatoid arthritis: a potential biomarker for radiographic progression. Clin Rheumatol 2013;32:1661-1666.

10. Cooper DL, Martin SG, Robinson JI, Mackie SL, Charles CJ, Nam J, et al. FcyR】a expression on monocytes in rheumatoid arthritis: role in immune-complex stimulated TNF production and nonresponse to methotrexate therapy. PLoS One 2012;7:e28918.

11. De Rotte MCFJ, Pluijm SMF, de Jong PHP, Bulatovic Calasan M, Wulffraat NM, Weel AEAM, et al. Development and validation of a prognostic multivariable model to predict insufficient clinical response to methotrexate in rheumatoid arthritis. PLoS One 2018;13:e0208534.

12. Sergeant JC, Hyrich KL, Anderson J, Kopec-Harding K, Hope HF, Symmons DPM, et al. Prediction of primary non-response to methotrexate therapy using demographic, clinical and psychosocial variables: results from the UK Rheumatoid Arthritis Medication Study (RAMS). Arthritis Res Ther 2018;20:147.

13. Teitsma XM, Jacobs JWG, Weising PMJ, de Jong PHP, Hazes JMW, Weel AEAM, et al. Inadequate response to treat-to-target methotrexate therapy in patients with new-onset rheumatoid arthritis: development and validationof clinical response. Ann Rheum Dis 2018;77:1261-1267.

14. Milic V, Jekic B, Lukovic L, Bunjevacki V, Milasin J, Novakovic I, Damnjanovic T, Popovic B, Maksimovic N, Damjanov N, Radunovic G, Pejnovic N, Krajinovic M. Association of dihydrofolate reductase (DHFR) -317AA genotype with poor response to methotrexate in patients with rheumatoid arthritis. Clin Exp Rheumatol. 2012;30: 178-83.

15. Gorlick R, Goker E, Trippett T, Steinherz P, Elisseyeff Y, Mazumdar M, Flintoff WF, Bertino JR. Defective transport is a common mechanism of acquired methotrexate resistance in acute lymphocytic leukemia and is associated with decreased reduced folate carrier expression. Blood 1997;89:1013-8.

16. Rothem L, Ifergan I, Kaufman Y, Priest DG, Jansen G, Assaraf YG. Resistance to multiple novel antifolates is mediated via defective drug transport resulting from clustered mutations in the reduced folate carrier gene in human leukaemia cell lines. Biochem J. 2002;367:741-50.

17. Kim JS, Lowe KE, Shane B. Regulation of folate and one-carbon metabolism in mammalian cells. IV. Role of folylpoly-gamma-glutamate synthetase in methotrexate metabolism and cytotoxicity. J Biol Chem. 1993;268:21680-5.

18. Hall MJ, Lawrence DA, Lansiedel JC, Walsh AC, Comstock LL, Kremer JM. Long-term exposure to methotrexate induces immunophenotypic changes, decreased methotrexate uptake and increased dihydrofolate gene copy number in Jurkat T cells. Int J Immunopharmacol. 1997;19:709-20.

19. Matherly LH, Taub JW, Ravindranath Y, Proefke SA, Wong SC, Gimotty P, Buck S, Wright JE, Rosowsky A. Elevated dihydrofolate reductase and impaired methotrexate transport as elements in
methotrexate resistance in childhood acute lymphoblastic leukemia. Blood 1995;85:500-9.

20. Banerjee D, Ercikan-Abali E, Waltham M, Schnieders B, Hochhauser D, Li WW, Fan J, Gorlick R, Goker E, Bertino JR. Molecular mechanisms of resistance to antifolates, a review. Acta Biochim Pol. 
1995;42:457-64.

21. Bertino JR, Goker E, Gorlick R, Li WW, Banerjee D. Resistance mechanisms to methotrexate in tumors. Stem Cells 1996;14:5-9.

22. Rhee MS, Wang Y, Nair MG, Galivan J. Acquisition of resistance to antifolates caused by enhanced gamma-glutamyl hydrolase activity. Cancer Res. 1993;53:2227-30.

23. Waltham MC, Li WW, Gritsman H, Tong WP, Bertino JR. gamma-Glutamyl hydrolase from human sarcoma HT-1080 cells: characterization and inhibition by glutamine antagonists. Mol Pharmacol. 1997;51:825-32.

24. Kunishio K, Okada M, Matsumoto Y, Nagao S. Preliminary individual adjuvant chemotherapy for primary central nervous system lymphomas based on the expression of drug-resistance genes. Brain Tumor Pathol. 2004;21:57-61.

25. Volk EL, Farley KM, Wu Y, Li F, Robey RW, Schneider E. Overexpression of wild-type breast cancer resistance protein mediates methotrexate resistance. Cancer Res. 2002;62:5035-40.

26. van der Heijden JW, Oerlemans R, Tak PP, Assaraf YG, Kraan MC, Scheffer GL, van der Laken CJ, Lems WF, Scheper RJ, Dijkmans BA, Jansen G. Involvement of breast cancer resistance protein expression on rheumatoid arthritis synovial tissue macrophages in resistance to methotrexate and leflunomide. Arthritis Rheum. 2009;60: 669-77.

27. Chen ZS, Robey RW, Belinsky MG, Shchaveleva I, Ren XQ, Sugimoto Y, Ross DD, Bates SE, Kruh GD. Transport of methotrexate, methotrexate polyglutamates, and 17beta-estradiol 17-(beta-Dglucuronide) by ABCG2: effects of acquired mutations at R482 on methotrexate transport. Cancer Res. 2003;63:4048-54.

28. Volk EL, Schneider E. Wild-type breast cancer resistance protein (BCRP/ABCG2) is a methotrexate polyglutamate transporter. Cancer Res. 2003;63:5538-43.

29. Muto S, lida K, Shinoda K, Saitoh M, Tsumura N, Shinohara E, Asayama T, Ishida S, Ihara H, Ogura T, Ogawa T, Saito E. High expression of breast cancer resistance protein is correlated with the resistance to methotrexate in patients with rheumatoid arthritis. Pharmacometrics 2015;88:31-8.

30. Van Gestel AM, Prevoo ML, van't Hof MA, van Rijswijk MH, van de Putte LB, van Riel PL. Development and validation of the European League Against Rheumatism response criteria for rheumatoid arthritis. Comparison with the preliminary American College of Rheumatology and the World Health Organization/International League Against Rheumatism Criteria. Arthritis Rheum 1996;39:34-40.

31. Kanda Y. Investigation of the freely available easy-to-use software 'EZR' for medical statistics. Bone Marrow Transplant. 2013; 48: 452-458.

32. Cronstein BN, Aune TM. Methotrexate and its mechanisms of action in inflammatory arthritis. Nat Rev Rheumatol 2020;16:145-154.

33. Nakamura S, Suzuki K, lijima H, Hata Y, Lim CR, Ishizawa Y, et al. Identification of baseline gene expression signatures predicting therapeutic responses to three biologic agents in rheumatoid arthritis: a retrospective observational study. Arthritis Res Ther 2016;18:159. 
34. Isshiki M, Umezawa K, Tamura H. Coffee induces breast cancer resistance protein expression in Caco-2 cells. Biol Pharm Bull. 2011;34:1624-7.

35. Wang $X$, Wu X, Wang C, Zhang W, Ouyang $Y, Y u$ Y, He Z. Transcriptional suppression of breast cancer resistance protein (BCRP) by wild-type p53 through the NF-kB pathway in MCF-7 cells. FEBS Lett. 2010;584:3392-7.

36. Mosaffa F, Lage H, Afshari JT, Behravan J. Interleukin-1 beta and tumor necrosis factor-alpha increase ABCG2 expression in MCF-7 breast carcinoma cell line and its mitoxantrone-resistant derivative, MCF-7/MX. Inflamm Res. 2009;58:669-76.

37. Pradhan M, Bembinster LA, Baumgarten SC, Frasor J. Proinflammatory cytokines enhance estrogendependent expression of the multidrug transporter gene ABCG2 through estrogen receptor and NFKB cooperativity at adjacent response elements. J Biol Chem 2010;285:31100-6.

38. Poller B, Drewe J, Krähenbühl S, Huwyler J, Gutmann H. Regulation of BCRP (ABCG2) and Pglycoprotein (ABCB1) by cytokines in a model of the human blood-brain barrier. Cell Mol Neurobiol. 2010;30:63-70.

39. Mosaffa F, Kalalinia F, Lage H, Afshari JT, Behravan J. Pro-inflammatory cytokines interleukin-1 beta, interleukin 6, and tumor necrosis factor-alpha alter the expression and function of ABCG2 in cervix and gastric cancer cells. Mol Cell Biochem. 2012;363:385-93.

\section{Figures}
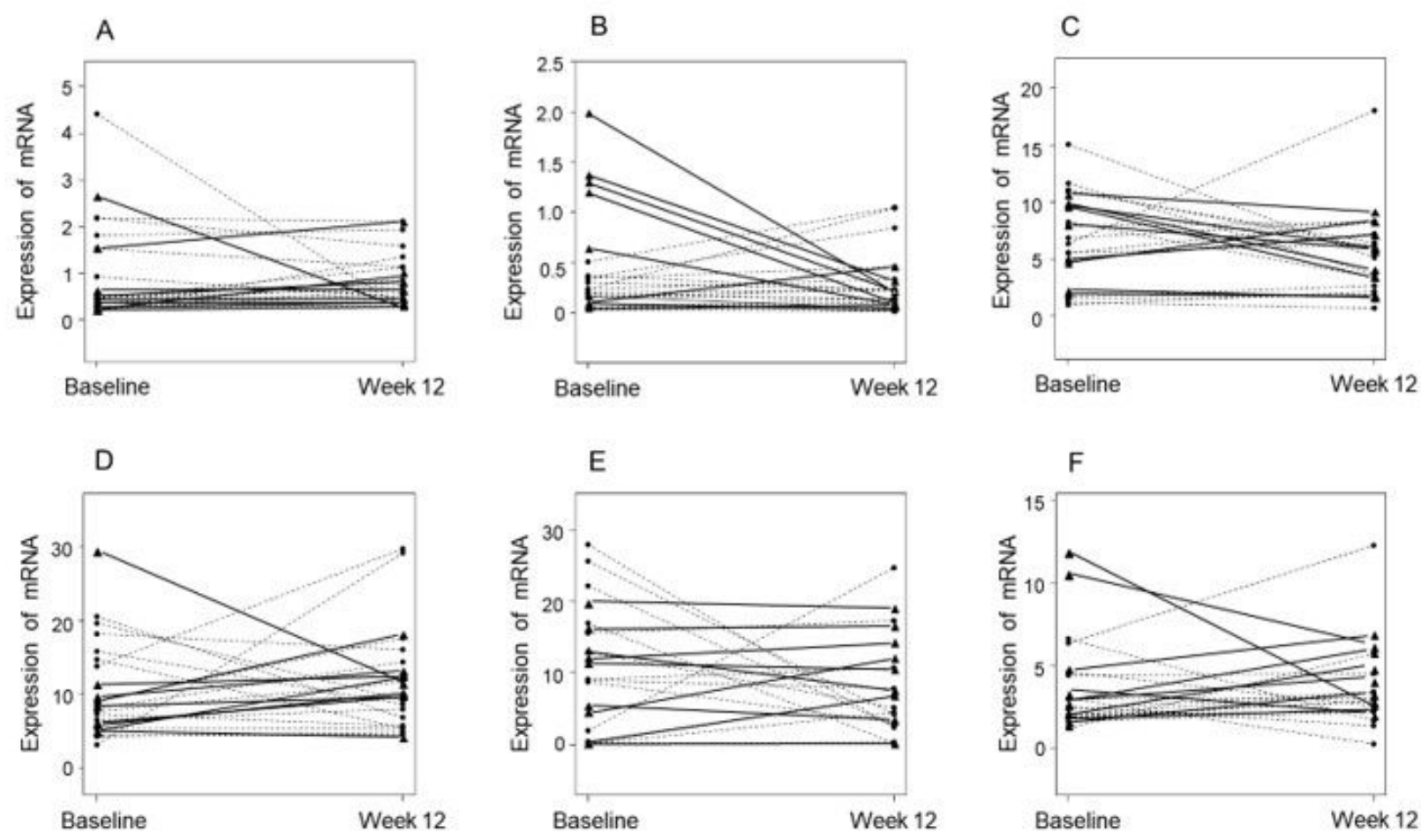

$\downarrow$ Good responders

$\bullet-$ Non-good responders 
Figure 1

Changes in mRNA expression levels of MTX-related genes during 12 weeks of MTX treatment $\triangle A ; A B C C 1$, $B ; A B C G 2$, C; DHFR, D; FPGS, E; GGH, F; RFC1. mRNA expression is provided as a \% of GAPDH expression.
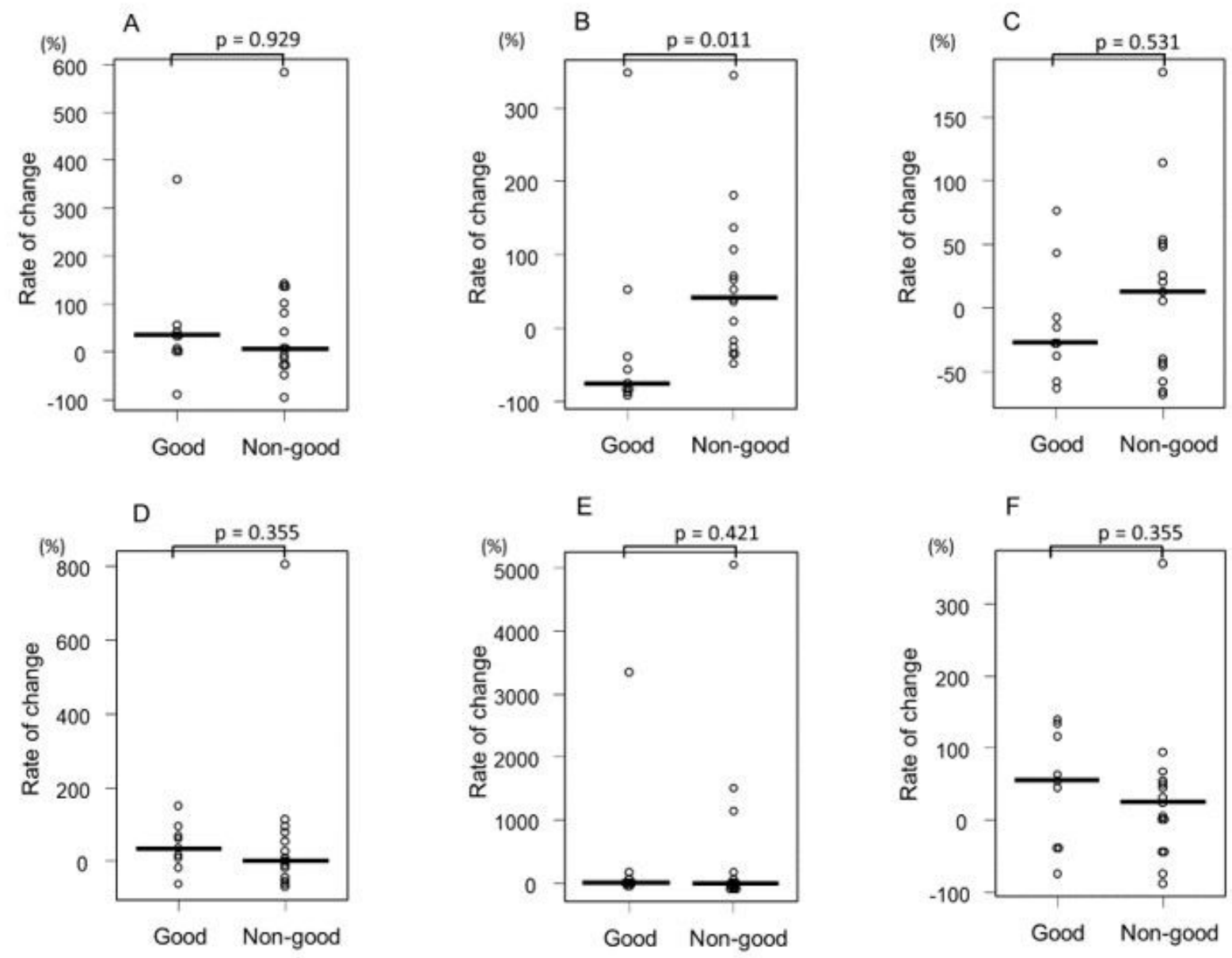

Figure 2

Comparison of the rate of change in mRNA expression level of MTX-related genes between good and non-good responders. A; ABCC1, B; ABCG2, C; DHFR, D; FPGS, E; GGH, F; RFC1. The values are expressed as the $\%$ change of mRNA expression over 12 weeks. A Mann-Whitney $U$ test was used for group comparisons. 

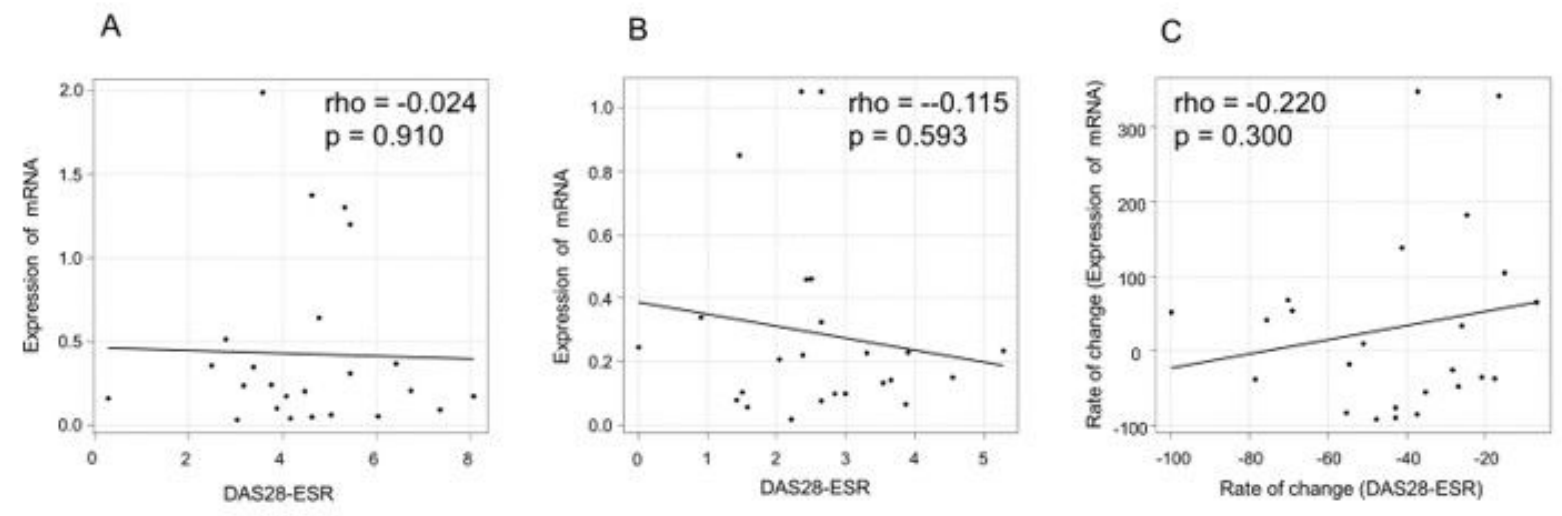

\section{Figure 3}

Relationship between ABCG2 mRNA expression and DAS28-ESR. At baseline (A) , at week 12 (B), and rates of change during 12 weeks of MTX treatment (C). The correlation was assessed using Spearman's rank correlation coefficient (rho).

\section{Supplementary Files}

This is a list of supplementary files associated with this preprint. Click to download.

- Supplementary.docx 